\title{
Rapid and Sensitive Detection of Apple stem pitting virus in Apple Trees Through RNA Amplification and Probing with Fluorescent Molecular Beacons
}

\author{
M. M. Klerks, G. Leone, J. L. Lindner, C. D. Schoen, and J. F. J. M. van den Heuvel
}

First, second, third, and fourth authors: Plant Research International BV, PO Box 16, 6700 AA Wageningen, the Netherlands; and fifth author: De Ruiter Seeds, P.O. Box 1050, 2660 BB Bergschenhoek, the Netherlands.

Accepted for publication 2 July 2001.

\begin{abstract}
Klerks, M. M., Leone, G., Lindner, J. L., Schoen, C. D., and van den Heuvel, J. F. J. M. 2001. Rapid and sensitive detection of Apple stem pitting virus in apple trees through RNA amplification and probing with fluorescent molecular beacons. Phytopathology 91:1085-1091.

Currently, detection of Apple stem pitting virus (ASPV; genus Foveavirus) in apple trees for certification purposes occurs by woody indexing. This method requires a minimum of 12 to 24 weeks in greenhouse testing to up to 2 years in field testing. In this paper, the development of a single tube AmpliDet RNA system for the rapid gel-free detection of ASPV in apple tree tissues is described. The system relies on

mum of 100 molecules of transcript RNA was obtained by the ASPVspecific AmpliDet RNA. All biologically characterized ASPV isolates from a field trial and 12 of 14 isolates from a plant virus collection were readily detected with this AmpliDet RNA system. In addition, the efficiency of this method for detecting ASPV in 'Golden Delicious' and 'Gravenstein' apple trees was compared throughout the year with mechanical inoculation onto Nicotiana occidentalis 37B, a candidate indicator for ASPV. This revealed that only AmpliDet RNA consistently detected the virus in bark tissue, irrespective of the season. Seasonspecific tissues such as buds, petals, and fruits, but not leaves, also were reliable sources for detection of ASPV by the AmpliDet RNA system.
\end{abstract} the specific amplification of the viral RNA by nucleic acid sequencebased amplification and the simultaneous fluorescent detection of the amplification product through molecular beacons. A sensitivity of a mini-
Additional keywords: fruit viruses, isothermal amplification, pome fruits, real-time detection.
Apple stem pitting virus (ASPV) is commonly present in commercial apple cultivars worldwide. It consists of flexible filamentous particles, 12 to $15 \mathrm{~nm}$ wide and $800 \mathrm{~nm}$ long, with a single-stranded RNA genome of 9,306 nucleotides $(5,8)$. The virus has recently been grouped into the new plant virus genus, Foveavirus (14). ASPV frequently occurs in combination with other viruses such as Apple chlorotic leafspot virus and Apple stem grooving virus (10). A number of disease syndromes are suspected to be caused by ASPV, but only pear vein yellows disease has been demonstrated to be caused by an isolate of ASPV $(10,16)$. Although commercial apple and pear varieties are usually symptomless when infected with ASPV, symptoms do occur on sensitive woody indicator plants (21). Transmission of ASPV to woody host plants occurs presumably by grafting only because a vector is not yet known.

Currently, routine ASPV detection is based on biological indexing by grafting bark or buds on woody indicator hosts $(2,17)$. Woody indexing is the only method accepted by inspection services during certification procedures (1). Greenhouse indexing with woody plants requires at least 12 to 24 weeks, whereas indexing in the fields can take up to 2 years to complete, the time needed for symptoms to appear. To enable a less time-consuming detection of ASPV in woody hosts, a biological indexing method was developed based on mechanical inoculation of woody tissues onto the herbaceous host Nicotiana occidentalis $37 B(8-10) . N$. occidentalis $37 \mathrm{~B}$ is now listed as a candidate herbaceous indicator for ASPV (1). More recently, reverse transcription-polymerase chain reaction (RT-PCR) systems and a plate-trapped enzymelinked immunosorbent assay for the detection of ASPV have been

Corresponding author: M. M. Klerks; E-mail address: M.M.Klerks@plant.wag-ur.nl

Publication no. P-2001-0906-01R

(C) 2001 The American Phytopathological Society developed $(6,13,15,16)$. The RT-PCR systems rely on a separate RT and PCR amplification prior to gel-based detection of the specific amplification products. To enable a gel-free and, therefore, faster detection of ASPV in different woody plant tissues, a novel detection (AmpliDet RNA) system was developed.

AmpliDet RNA consists of the nucleic acid sequence-based amplification (NASBA) technology combined with a molecular beacon detection probe, performed in a single tube (11). NASBA is an isothermal nucleic acid amplification method that amplifies RNA (viral RNA, mRNA, and rRNA) using oligonucleotide primers and the enzymes Avian myoblastosis virus (AMV)-RT, RNase $\mathrm{H}$, and T7 RNA polymerase. The amplification product consists of single-stranded antisense RNA products that are formed to a billionfold extent $(3,7)$.

Molecular beacons are single-stranded oligonucleotides containing a $5^{\prime}$ and $3^{\prime}$ complementary sequence forming a stem-loop structure when unbound (19). A fluorescent dye and a quencher are labeled on, respectively, the $5^{\prime}$ end and the $3^{\prime}$ end of the molecular beacon. The loop sequence is complementary to its target sequence. When no target is present, the fluorescence is quenched due to a mechanism distinct from fluorescence resonance energy transfer $(18,20)$. In the presence of a target molecule, the loop sequence of the molecular beacon hybridizes to it, forcing the stem to unfold. The fluorescent dye will no longer be quenched and thus yields a fluorescent signal (Fig. 1). Combining NASBA with molecular beacons enables the simultaneous amplification and detection of target RNA in a single closed tube, potentially providing a more suitable system for routine diagnostics due to the reduction of labor and misdiagnosis (i.e., by limiting carryover contamination) (11).

In this paper, we describe our procedures for AmpliDet RNA analysis and its application for the rapid detection of ASPV in different apple tree tissues year round. We show that ASPV 
isolates, characterized in field trials through biological indexing on apple and pear indicators $(9,10)$, and a number of partially characterized isolates are readily detected by this gel-free system. Moreover, a comparison between analyses of samples through AmpliDet RNA versus mechanical inoculation to the herbaceous host, $N$. occidentalis $37 B$ (8), was performed. To determine the best sampling tissue and detection method, samples from different apple trees were taken monthly throughout a 1-year period and tested for ASPV by both methods.

\section{MATERIALS AND METHODS}

Plant material and virus isolates. Biologically characterized ASPV isolates, maintained in $N$. occidentalis $37 B$, were obtained through back transmission from the herbaceous host to apple and indexing of grafted bark and buds from infected apple trees on apple indicator trees in a field trial $(9,10)$.

Commercial cultivars of apple (Golden Delicious and Gravenstein) infected with ASPV were obtained by grafting bark and buds from the biologically characterized ASPV-infected apple seedlings onto the stem $(9,10)$. Infected tissue from these commercial apple varieties was used for mechanical inoculation onto the herbaceous test plant, $N$. occidentalis $37 B$, and for optimizing the AmpliDet RNA system. From each variety, tissue samples (bark, buds, leaves, petals, and fruit) were randomly collected separately from three trees infected with ASPV isolate 3536 and one noninfected tree and used for further analysis at monthly intervals. These samples were ground in a $1 \%$ nicotine solution prior to RNA extraction with RNeasy (Qiagen, Hilden, Germany) and mechanical inoculation onto $N$. occidentalis $37 B$; each sample was tested five times by mechanical inoculation to individual $N$. occidentalis $37 B$ plants and at least twice through AmpliDet RNA. In total, five biologically characterized isolates and 14 partially characterized isolates (maintained in herbaceous test plants) were used throughout the experiments.
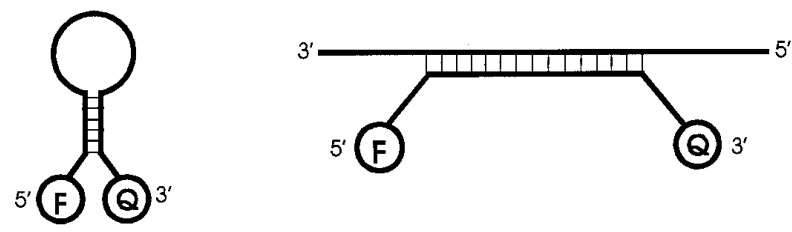

Fig. 1. Structure of a molecular beacon with (right) and without (left) template. The molecular beacon in the closed nonfluorescing state shows a typical stem-loop structure. 4-[4'-dimethylaminophenylazo]-benzoic acid, refered to as $(\mathrm{Q})$, quenches the fluorescence of the fluorescent dye, i.e., fluorescein $(\mathrm{F})$, when the molecular beacon is not hybridized to its target. When the loop-sequence is hybridized to the target sequence, the stem structure is forced to open and fluorescence is no longer quenched.
Primers and probes. Design of the ASPV-specific primers P1 and P2a for amplification of the viral RNA by NASBA (Organon Teknika BV., Boxtel, the Netherlands) was based on the coat protein (CP)-encoding region of ASPV (16), and flanked a sequence of 273 nucleotides. The primer P1 consisted of a $3^{\prime}$ target complementary sequence and a $5^{\prime} \mathrm{T} 7 \mathrm{RNA}$ polymerase recognition-site sequence. To further optimize the ASPV-specific NASBA, the primers $\mathrm{P} 2 \mathrm{~b}$ and $\mathrm{P} 2 \mathrm{c}$ were designed based on sequence homology of published and newly generated sequences of different ASPV isolates within the CP-encoding region. The primers flanked ASPV-specific sequences of 244 (P2b) and 172 (P2c) nucleotides. To generate RT-PCR amplification products covering the NASBA products, specific primers (FP and RP) were designed within the $\mathrm{CP}$-encoding region of ASPV, which included a virusspecific sequence of 463 nucleotides. For optimization of the NASBA system, transcript RNA was generated by RT-PCR, using primer RP and a modified primer FP, containing a 5' T7 RNA polymerase recognition-site sequence. The RT-PCR product was transcribed by T7 RNA polymerase generating single-stranded (+) transcript RNA, including a virus-specific sequence of $463 \mathrm{nu}-$ cleotides. The transcript RNA was purified from gel, and the concentration was determined by photospectrometric measurements.

A virus-specific molecular beacon, designated MB, was developed to enable real-time detection of NASBA products. The molecular beacon carried a $5^{\prime}$ and $3^{\prime}$ arm sequence of 6 nucleotides and a loop sequence of 20 nucleotides complementary to the specific NASBA product. The arm sequences formed a doublestranded structure at $41{ }^{\circ} \mathrm{C}$ to avoid fluorescence from nonhybridized molecular beacons and were designed to prevent hybridization with the NASBA products. The molecular beacons were labeled with 6-carboxyfluorescein (FAM) and the nonfluorescent quencher 4-[4'-dimethylaminophenylazo]-benzoic acid (DABCYL) at the $5^{\prime}$ and $3^{\prime}$ ends, respectively.

To detect specific NASBA products of ASPV by chemiluminescent northern blotting, biotinylated probes were used. The biotinylated probe $\mathrm{Bio} 2$ was developed to hybridize to the same region within the amplification product as the molecular beacon MB. Sequences and locations of the primers, molecular beacons, and probes on the viral genome are listed in Table 1.

NASBA. The NASBA was performed as previously described $(3,7)$. The NASBA reaction mix consisted of $5 \mu$ of NASBA reagents $\left(160 \mathrm{mM}\right.$ Tris- $\mathrm{HCl}, \mathrm{pH} 8.5,48 \mathrm{mM} \mathrm{MgCl}_{2}, 2 \mathrm{mM}$ dithiothreitol, $4 \mathrm{mM}$ dNTP, $8 \mathrm{mM}$ each of ATP, UTP, and CTP, $6 \mathrm{mM}$ GTP, and $2 \mathrm{mM} \mathrm{ITP}), 0.7 \mu \mathrm{l}$ of $350 \mathrm{mM} \mathrm{KCL}, 4 \mu \mathrm{l}$ of $5 \times$ primer mix (75\% dimethyl sulfoxide and $1 \mu \mathrm{M}$ each primer), and $2.3 \mu \mathrm{l}$ of RNase-free water per reaction. A volume of $3 \mu$ of sample solution (extracted RNA) or water (negative control) was added to the NASBA reaction mix. The reactions were preincubated at $65^{\circ} \mathrm{C}$ followed by $41^{\circ} \mathrm{C}$ for $5 \mathrm{~min}$ each. The NASBA reaction was started by adding $5 \mu \mathrm{l}$ of enzyme mix ( $375 \mathrm{mM}$ sorbitol, $2.1 \mu \mathrm{g}$ of bovine serum albumin, 0.08 units of RNase $\mathrm{H}, 32$ units of $\mathrm{T} 7$

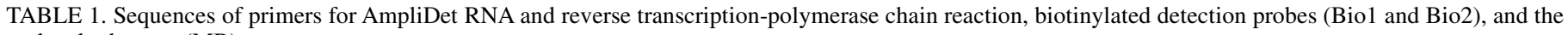
molecular beacon (MB)

\begin{tabular}{|c|c|c|c|c|}
\hline Oligonucleotides $^{\mathrm{a}}$ & Sequence $\left(5^{\prime}-3^{\prime}\right)^{\mathrm{b}}$ & Length & Position $^{\mathrm{c}}$ & Type \\
\hline NASBA primer $P 1^{d}$ & AAT TCT AAT ACG ACT CAC TAT AGG G AG GAC TTT GAG TTT GCA GCA TGA & $48 \mathrm{nt}$ & $8885-8906$ & Antisense \\
\hline NASBA primer $\mathrm{P} 2 \mathrm{a}$ & $\overline{\text { CGA GCA ATC AAA AGA TCA GA }}$ & $21 \mathrm{nt}$ & $8633-8653$ & Sense \\
\hline NASBA primer $\mathrm{P} 2 \mathrm{~b}$ & GTT GCA CTC ATT GGA ATG GGA A & $22 \mathrm{nt}$ & $8662-8683$ & Sense \\
\hline NASBA primer P2c & GCA GAT GTT GGA GCC TCA GA & $20 \mathrm{nt}$ & $8734-8753$ & Sense \\
\hline PCR primer RP & CTC GTG GCA TTG GCT ACC CTC TCA & $24 \mathrm{nt}$ & $9036-9059$ & Antisense \\
\hline PCR primer FP & AAC ATC AGG TAT GAA CCC CAG GCT & $24 \mathrm{nt}$ & $8599-8622$ & Sense \\
\hline Detection probe 1 (Bio1) & B-CGC AGA TGT TGG CGC CTC AGA C & $22 \mathrm{nt}$ & $8733-8754$ & Sense \\
\hline Detection probe 2 (Bio2) & B-ACG CAA AGC ATG TCT GGA AC & $20 \mathrm{nt}$ & $8864-8883$ & Sense \\
\hline Molecular beacon (MB) & FAM-GCT CCA ACG CAA AGC ATG TCT GGA ACT GGA GC-DABCYL & $32 \mathrm{nt}$ & $8864-8883$ & Sense \\
\hline
\end{tabular}

a NASBA = nucleic acid sequence-based amplification.

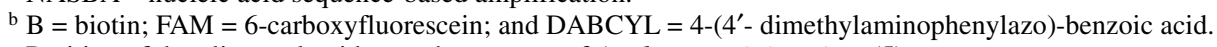

c Position of the oligonucleotides on the genome of Apple stem pitting virus (5).

${ }^{\mathrm{d}}$ Primer P1 consists of a 3' target complementary sequence and a 5' T7 RNA polymerase recognition-site sequence of 25 nucleotides (underlined). 
RNA polymerase, and 6.4 units of AMV-RT) per reaction, incubated for $5 \mathrm{~min}$ at $41^{\circ} \mathrm{C}$, and briefly centrifuged followed by incubation for $90 \mathrm{~min}$ at $41^{\circ} \mathrm{C}$. Real-time amplification and detection by AmpliDet RNA was carried out as described previously, except that the $2.3 \mu \mathrm{l}$ of RNase-free water was replaced by $1 \mu \mathrm{l}$ of $10 \mu \mathrm{M}$ ROX (5-[and 6]-carboxy-X-rhodamine), $1 \mu \mathrm{l}$ of molecular beacon solution $(9 \mathrm{ng} / \mu \mathrm{l})$, and $0.3 \mu \mathrm{l}$ of RNase-free water. The ROX and molecular beacons were all prepared in RNase-free water. The 90-min incubation at $41^{\circ} \mathrm{C}$ was performed in a thermal cycler (ABI Prism 7700; Applera Corporation, Norwalk, CT), and the emission spectrum of FAM was measured in real-time for each sample every $2 \mathrm{~min}$. All reactions were performed at least twice.

RT-PCR and sample preparation for sequencing. Each RT reaction was performed with $10 \mu \mathrm{l}$ of sample in $20 \mu \mathrm{l}$ of RT1-mix, consisting of $5 \mu \mathrm{l}$ of $10 \times$ PCR Gold Buffer $(150 \mathrm{mM}$ Tris- $\mathrm{HCl}$, $\mathrm{pH} 8.05$, and $500 \mathrm{mM} \mathrm{KCl}$ ), $25 \mathrm{mM} \mathrm{MgCl}_{2}, 10$ units of RNaseinhibitor, $3.5 \mu \mathrm{l}$ of RNase-free water, and $3 \mu \mathrm{l}$ of primer RP $(5 \mu \mathrm{M})$. The sample was heated for $5 \mathrm{~min}$ at $65^{\circ} \mathrm{C}$ followed by a $5-\mathrm{min}$ incubation at $23^{\circ} \mathrm{C}$. After this incubation, $20 \mu \mathrm{l}$ of RT2-mix $(5 \mu \mathrm{l}$ of dNTP-solution [10 mM each of dNTP diluted in RNase-free water], 10 units of RNase-inhibitor, 12.5 units of RT-Moloney murine leukemia virus, and $14.25 \mu \mathrm{l}$ of RNase-free water) was added to the sample. The sample was incubated at $37^{\circ} \mathrm{C}$ for $120 \mathrm{~min}$ and $95^{\circ} \mathrm{C}$ for $5 \mathrm{~min}$. The RT products were stored at $-20^{\circ} \mathrm{C}$ before use.

PCR was performed by adding $5 \mu$ of RT product to a PCR mix consisting of $5 \mu \mathrm{l}$ of $10 \times$ PCR Gold Buffer, $8 \mu \mathrm{l}$ of $25 \mathrm{mM} \mathrm{MgCl}_{2}$, $5 \mu \mathrm{l}$ of dNTP solution (10 mM each of dNTP diluted in RNase-free water), $1 \mu \mathrm{l}$ of primer FP $(5 \mu \mathrm{M}), 1 \mu \mathrm{l}$ of primer RP $(5 \mu \mathrm{M}), 2.5$ units of AmpliTaq Gold DNA polymerase, and $24.5 \mu$ l of RNase-free water. The total mix was preheated in a thermal cycler at $94^{\circ} \mathrm{C}$ for $10 \mathrm{~min}$, followed by 49 cycles of $15 \mathrm{~s}$ at $94^{\circ} \mathrm{C}, 30 \mathrm{~s}$ at $60^{\circ} \mathrm{C}$, and $1 \mathrm{~min}$ at $72^{\circ} \mathrm{C}$. Samples were stored at $-20^{\circ} \mathrm{C}$ for further analysis.

For purifying the specific PCR amplification products, the entire PCR reaction volume was loaded on a $1 \%$ pronarose gel

\section{A}
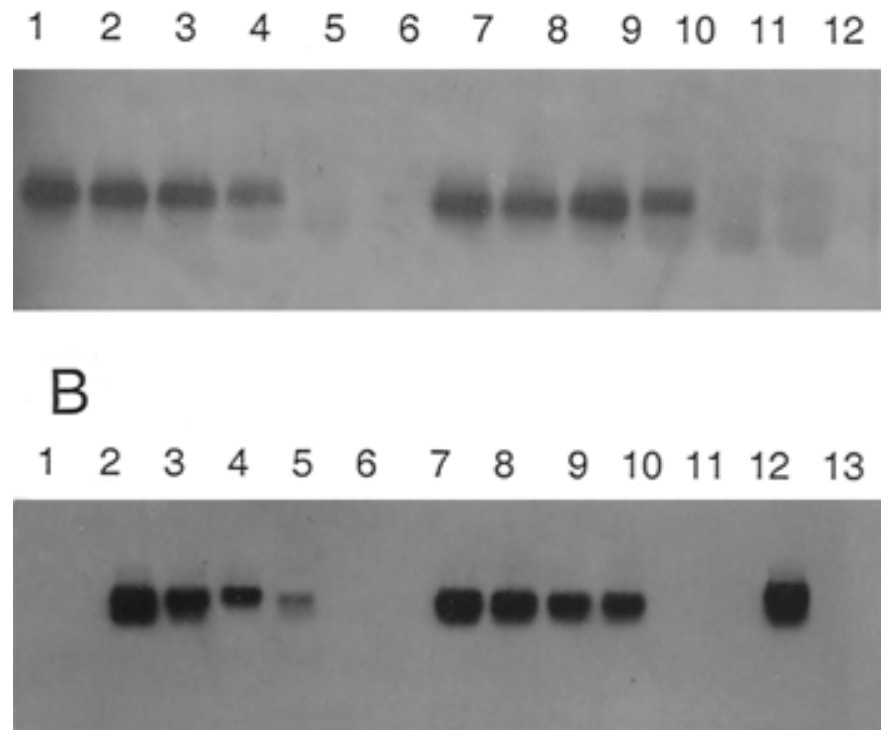

Fig. 2. Detection of Apple stem pitting virus amplification products using northern blotting and enhanced chemiluminescence detection. The primer combination A, P1,P2a (lanes 1 to 12), and $\mathbf{B}, \mathrm{P} 1, \mathrm{P} 2 \mathrm{~b}$ (lanes 1 to 6 ) and $\mathrm{P} 1, \mathrm{P} 2 \mathrm{c}$ (lanes 7 to 12 ) were tested in nucleic acid sequence-based amplification with a dilution series containing (lanes 1 and 7), 105; (lanes 2 and 8), 104; (lanes 3 and 9), 103; (lanes 4 and 10), 102; (lanes 5 and 11), 10 molecules of transcript RNA of A and B, isolate 3049, and B, isolate Gloster passage; (lanes 6 and 12), a negative control (water); and $\mathbf{B}$, (lane 13), a positive control containing $10^{5}$ molecules of transcript RNA, amplified with the primer combination P1,P2a. All specific amplification products were detected with the biotin-labeled probe $\mathbf{A}$, Bio1 or $\mathbf{B}$, Bio2. containing $0.5 \mu \mathrm{g}$ of ethidium bromide $(\mathrm{EtBr})$ per $\mathrm{ml}$ and run at $100 \mathrm{~V}$ for $60 \mathrm{~min}$ in buffer containing $45 \mathrm{mM}$ Tris-borate and $1 \mathrm{mM}$ EDTA, pH 8.0. The DNA bands were purified from the gel and prepared for sequencing. Nucleotide sequencing was performed at the Wageningen University and Research Center (Wageningen, the Netherlands).

Detection of NASBA products by northern blotting and enhanced chemiluminescence. NASBA products were analyzed by electrophoresis using a $1 \%$ pronarose gel with $0.5 \mu \mathrm{g}$ of $\mathrm{EtBr}$ per $\mathrm{ml}$. Gels were run at $100 \mathrm{~V}$ for $15 \mathrm{~min}$ in buffer containing $40 \mathrm{mM}$ Tris-acetate and $1 \mathrm{mM}$ EDTA, pH 8.0 (1× TAE). The gel was blotted onto a Z-probe nylon membrane in $0.3 \mathrm{M} \mathrm{NaCl}$ and $30 \mathrm{mM}$ sodium citrate $(2 \times \mathrm{SSC})$ for $20 \mathrm{~min}$. Nucleic acids were cross-linked onto the Z-probe by UV exposure for $2 \mathrm{~min}$. Hybridization of the biotinylated probe $(3 \mu \mathrm{M})$ to the NASBA products was performed at $50^{\circ} \mathrm{C}$ for 30 to $60 \mathrm{~min}$ in $5 \times \mathrm{SSC}, 7 \%$ sodium dodecyl sulfate (SDS), $20 \mathrm{mM}$ Na-phosphate, $\mathrm{pH}$ 6.7, and $10 \times$ Denhardt's reagent. The blots were washed twice with $3 \times \mathrm{SSC}, 1 \% \mathrm{SDS}$ at $50^{\circ} \mathrm{C}$ for $5 \mathrm{~min}$, and once with buffer containing $0.1 \%$ SDS with $20 \mathrm{mM} \mathrm{Na} \mathrm{HPO}_{4}, 0.36 \mathrm{M} \mathrm{NaCl}$, and $2 \mathrm{mM}$ EDTA ( $2 \times \mathrm{SSPE})$ at room temperature for $10 \mathrm{~min}$. Subsequent steps were carried out at room temperature. The blots were incubated for $30 \mathrm{~min}$ with $2 \mu \mathrm{l}$ of streptavidin peroxidase conjugate in $5 \times$ SSPE with $0.5 \%$ SDS followed by extensive washing, incubated in enhanced chemiluminescence (ECL) detection reagents (Amersham Pharmacia Biotech, Freiburg, Germany), and exposed to X-ray films.

\section{RESULTS}

Development of an ASPV-specific AmpliDet RNA system. To develop an ASPV-specific AmpliDet RNA system, the primers P1 and $\mathrm{P} 2 \mathrm{a}$ were selected within the CP-encoding region (16). Dilution series of transcript RNA of two ASPV isolates were tested to determine the sensitivity of the NASBA amplification. Specific amplification products were detected with the biotinlabeled probe Biol in the ECL detection system, showing a detection level of at least 100 molecules of target transcript RNA (Fig. 2A).

TABLE 2. Apple stem pitting virus (ASPV) isolates tested using nucleic acid sequence-based amplification (NASBA) followed by enhanced chemiluminescent (ECL) detection or AmpliDet RNA, with different primer combinations $^{\mathrm{a}}$

\begin{tabular}{|c|c|c|c|c|}
\hline \multirow[b]{2}{*}{ ASPV isolate ${ }^{b}$} & \multicolumn{2}{|c|}{$\mathrm{ECL}^{\mathrm{c}}$} & \multicolumn{2}{|c|}{ AmpliDet RNA ${ }^{\mathrm{d}}$} \\
\hline & $\mathrm{P} 1, \mathrm{P} 2 \mathrm{a}$ & $\mathrm{P} 1, \mathrm{P} 2 \mathrm{a}$ & $\mathrm{P} 1, \mathrm{P} 2 \mathrm{~b}$ & $\mathrm{P} 1, \mathrm{P} 2 \mathrm{c}$ \\
\hline 3049 (b.c.) & + & - & + & + \\
\hline Gloster (b.c.) & + & + & + & + \\
\hline Gloster passage (b.c.) & + & - & + & + \\
\hline 3536 (b.c.) & + & + & + & + \\
\hline VA 2-5 (b.c.) & + & + & - & + \\
\hline Freriks & + & + & - & + \\
\hline LH 6-2 & + & + & + & + \\
\hline v. Dijk & + & + & + & + \\
\hline Stony pit PD & + & + & + & + \\
\hline v/d Grift & + & + & + & + \\
\hline Conference Lienden & + & - & + & + \\
\hline VO 25 & + & + & + & + \\
\hline PD 27-1 & - & + & + & + \\
\hline Schoen & - & + & + & + \\
\hline $13-9-11$ & + & - & + & + \\
\hline Polak & + & - & + & - \\
\hline Woets Lienden & + & - & - & + \\
\hline Ekmek & + & - & - & + \\
\hline LH 7-2 & + & + & - & - \\
\hline
\end{tabular}

a Positive results are indicated by + , and negative results are marked as -.

$\mathrm{b}$ The biologically characterized isolates are indicated by (b.c.).

${ }^{c}$ ECL was performed to detect specific NASBA products using the biotinlabeled probe Bio1.

d AmpliDet RNA was carried out with three different primer combinations. 
The specificity of NASBA was tested on ASPV isolates present in the field trial and in the plant virus collection of Plant Research International BV. $N$. occidentalis $37 B$ test plants were mechanically inoculated for each isolate and symptom development was followed. Leaves showing systemic symptoms were collected, and total RNA was extracted. ASPV could be detected in all samples of the biologically characterized isolates when tested by NASBA followed by ECL detection. Moreover, only 2 of the other 14 isolates were negative (Table 2). It was further observed that the intensities of the bands varied considerably among the different isolates, which suggested the presence of heterogeneity within the $\mathrm{CP}$-encoding sequence of the ASPV isolates.
To assess whether heterogeneity within the target region was indeed present, five isolates (PD27-1, Schoen, Conference Lienden, Gloster passage, and Stony Pit PD) showing different ECL intensities on X-ray films were sequenced by the PCR primers FP and RP flanking the NASBA product. This revealed a significant level of sequence heterogeneity within the amplification region among the isolates, showing a sequence homology of $82 \%$ or greater (Fig. 3). The hybridizing regions for forward primer P2a and the detection probe Bio1 showed up to four mismatches. This observation led to the development of a more generic primer set to efficiently detect all ASPV isolates available.

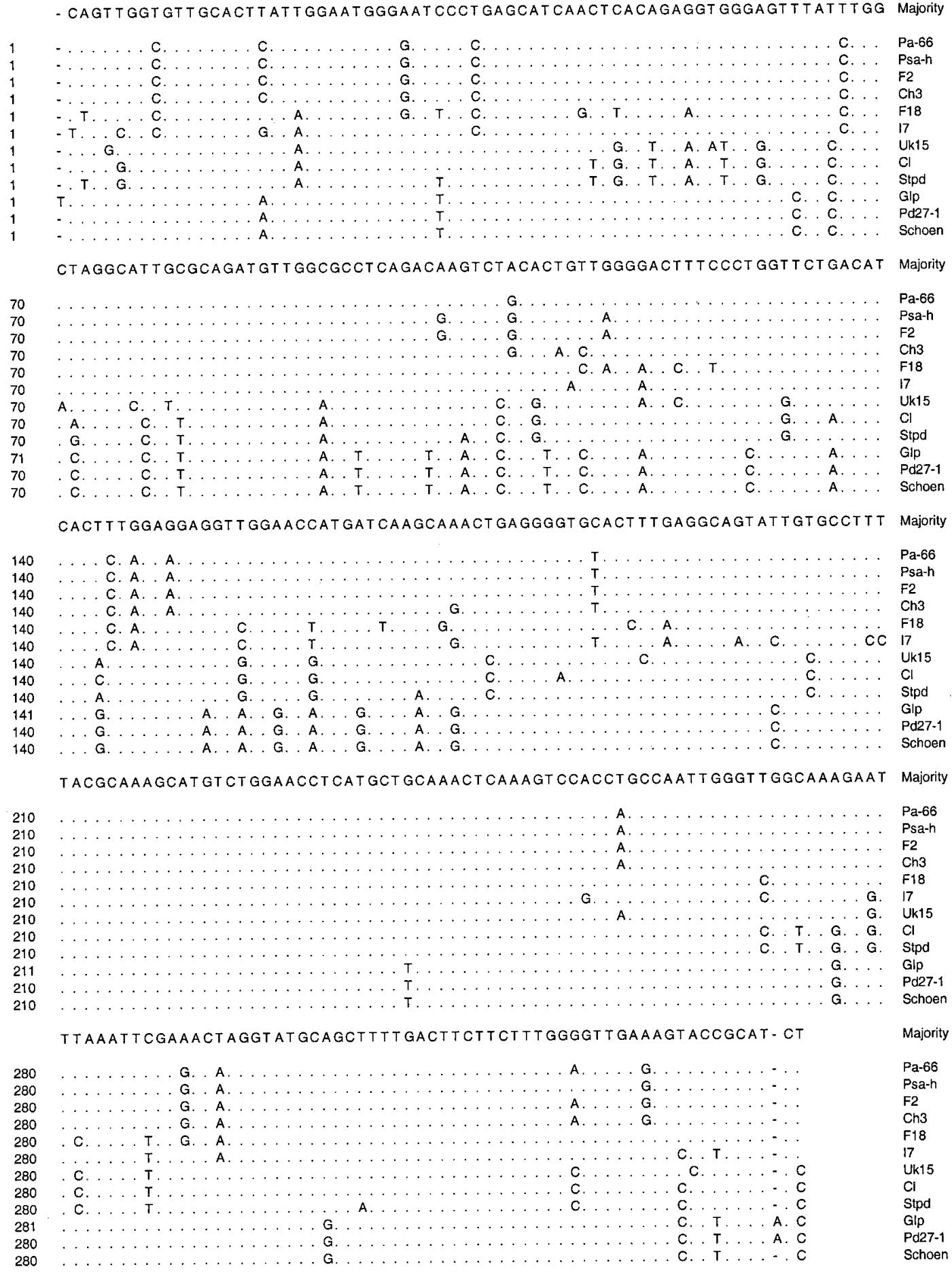

Fig. 3. Alignment of partial coat protein-related sequences of Apple stem pitting virus isolates. Isolates 1 to 7 represent extant sequences (16) and isolates 8 to 12 represent the new partially sequenced isolates Conference Lienden $(\mathrm{Cl})$, Standard PD (Stpd), Gloster passage (Glp), Pd27-1, and Schoen from the field trial and plant virus collection of Plant Research International BV. Dots represent residues with identity to the majority sequence. 
Optimization of AmpliDet RNA for detection of ASPV. Two new forward primers (P2b and P2c) and a new biotin-labeled probe (Bio2) were designed to develop a more generic NASBA for the detection of ASPV. These primers and probe were located in a more conserved area within the same CP-encoding region flanked by the PCR primers FP and RP. The sensitivity of the primer sets was tested by performing a NASBA on a dilution series of transcript RNA of ASPV and ECL detection using Bio2. The results showed a sensitivity of approximately 500 or 100 molecules of transcript RNA using each of the new primer sets $\mathrm{P} 1, \mathrm{P} 2 \mathrm{~b}$ or $\mathrm{P} 1, \mathrm{P} 2 \mathrm{c}$, respectively (Fig. 2B).

The MB oligonucleotide was designed for the development of an AmpliDet RNA in the same hybridizing sequence region as the detection probe Bio2. It was combined with the primer set $\mathrm{P} 1, \mathrm{P} 2 \mathrm{c}$ in NASBA because this set was the most sensitive. Tenfold dilution series of transcript RNA of ASPV was tested to determine the sensitivity of the AmpliDet RNA system. Results showed a sensitivity of at least 100 molecules of transcript RNA of ASPV, indicating that no decrease in sensitivity was introduced by the incorporation of the MB into the NASBA system (Fig. 4). Transcript RNA of all isolates was prepared and tested with the primer set P1,P2c to determine the specificity. The AmpliDet RNA enabled the detection of all isolates but two (Polak and LH7-2) (Table 2).

Year round detection of ASPV in apple trees using AmpliDet RNA and mechanical inoculation. The possibility of testing different apple tree tissues like bark, buds, leaves, petals, and fruits throughout the year was investigated. Each month, samples were collected from apple cvs. Golden Delicious and Gravenstein and tested by both AmpliDet RNA and mechanical inoculation onto $N$. occidentalis $37 B$. Results of AmpliDet RNA and mechanical inoculation when using bark as sampling tissue throughout the year are shown in Figure 5, and the results of the other tissues are shown in Table 3.

Throughout the year, bark appeared to be a good starting material to test trees for ASPV by AmpliDet RNA (Fig. 5). At each sampling date, at least five out of six infected trees obtained positive results after AmpliDet RNA. It should be noted that the same 'Golden Delicious' tree always provided false negative results with AmpliDet RNA. This tree continued to show erratic results throughout the experiments, irrespective of the tissue tested. Using mechanical inoculation, ASPV was detected in bark from January to June but not between July and November.

The AmpliDet RNA system enabled the detection of ASPV in buds from five out of six infected trees throughout the year, whereas mechanical inoculation did not allow a reliable detection of the virus in the bud tissue (Table 3). Leaves were not a good

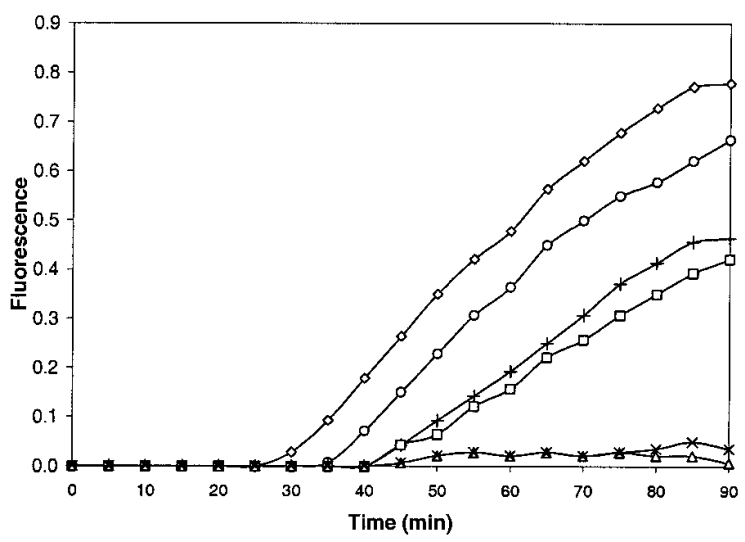

Fig. 4. Real-time detection of a dilution series of transcript RNA of Apple stem pitting virus using AmpliDet RNA. Tenfold dilution series of $10^{5}(\diamond)$, $10^{4}(0), 10^{3}(+), 10^{2}(\square)$, and $10(\triangle)$ molecules of transcript RNA, and a water control $(x)$ were tested using the primer combination P1,P2b and the molecular beacon probe. For each sample, the fluorescence increase is plotted in the graph as a function of time. source for detecting the virus (Table 3). Both methods yielded false negative results through time, with mechanical inoculation yielding only a few positive samples in late spring (May and June). In May, petals were tested and ASPV was detected in five of six infected trees with both AmpliDet RNA and mechanical inoculation. Fruits were suitable for a reliable detection of ASPV by AmpliDet RNA in October and November. Using mechanical inoculation, the virus could not be detected in fruits.

Influence of storage of petals and apples on ASPV detection. It was shown in the previous section that ASPV was readily detected in petals by AmpliDet RNA. Although petals are very season-specific, the major advantage of using them as testing samples is that they are much easier to process than all other tissues tested. This might be useful during diagnostic screening of fruit trees for ASPV and, in particular, if the petals can be stored before testing. To determine if ASPV was retained in petals during storage, a large number of petals from the six apple trees infected with ASPV isolate 3536 was collected. One batch was tested by AmpliDet RNA immediately after collection. The remaining batches of petals were stored at $-80^{\circ} \mathrm{C}$ and tested after 6 and 12 weeks. The results showed no difference in detection of ASPV in petals over time, indicating that sufficient viral RNA was present after storage to be detected. A positive result was shown from five out of six samples each time. The negative sample originated from the same 'Golden Delicious' tree responsible for the erratic results in the previous experiments. These results indicate that petals can therefore be suitable for rapid diagnostic screenings by inspection services in addition to bark tissue.

To investigate the influence of storage conditions of apples on virus detection, apples were tested after storage of 8 weeks at $4{ }^{\circ} \mathrm{C}$ and after 2 weeks of ripening at room temperature. From two ASPV-infected and one healthy 'Golden Delicious' tree, 36 apples (12 for each tree) were collected and stored at $4^{\circ} \mathrm{C}$. Using AmpliDet RNA, six apples from each tree were tested for the presence of ASPV. After 2 weeks at room temperature, all 36 apples were tested for ASPV by AmpliDet RNA. The virus was readily detected in all apples except for the healthy controls. The results showed no difference in testing immediately after storage at $4{ }^{\circ} \mathrm{C}$ or after 2 weeks of ripening at room temperature, indicating that the storage conditions do not influence the detectability of the virus by AmpliDet RNA.

\section{DISCUSSION}

The isothermal AmpliDet RNA system described in this paper was a powerful tool for the detection of ASPV in woody tissues.

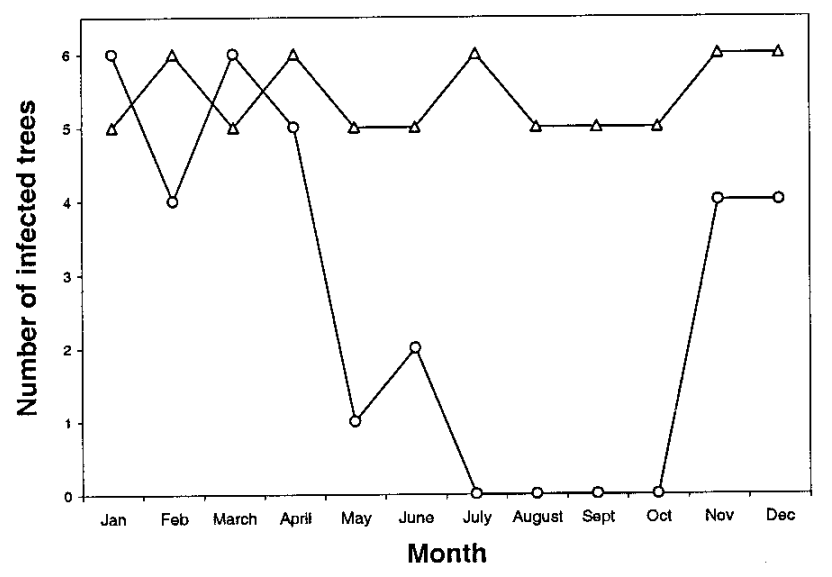

Fig. 5. Detection of Apple stem pitting virus in bark throughout the year using AmpliDet RNA and mechanical inoculation. For each method the total number of infected trees showing positive results is plotted in the graph for each month throughout the year. AmpliDet RNA results, $(\triangle)$; and mechanical inoculation results, $(\mathrm{O})$. 
TABLE 3. Detection of Apple stem pitting virus (ASPV) in different woody plant tissues over a 1-year period through mechanical inoculation of Nicotiana occidentalis $37 B$ or AmpliDet RNA ${ }^{\mathrm{a}}$

\begin{tabular}{|c|c|c|c|c|c|c|c|c|c|c|c|c|c|}
\hline Tissue & Detection & Jan & Feb & Mar & Apr & May & Jun & Jul & Aug & Sep & Oct & Nov & Dec \\
\hline \multirow[t]{2}{*}{ Buds } & Inoculation & $6 / 6$ & $2 / 6$ & $5 / 6$ & $3 / 6$ & $\ldots$ & $\ldots$ & $\ldots$ & $\ldots$ & $\ldots$ & $\ldots$ & $4 / 6$ & $1 / 6$ \\
\hline & AmpliDet RNA & $5 / 6$ & $6 / 6$ & $5 / 6$ & $5 / 6$ & $\cdots$ & $\ldots$ & $\ldots$ & $\ldots$ & $\ldots$ & $\cdots$ & $6 / 6$ & $6 / 6$ \\
\hline \multirow[t]{2}{*}{ Leaves } & Inoculation & $\ldots$ & $\ldots$ & $\ldots$ & $\ldots$ & $1 / 6$ & $3 / 6$ & $0 / 6$ & $0 / 6$ & $0 / 6$ & $0 / 6$ & $\ldots$ & $\ldots$ \\
\hline & AmpliDet RNA & $\cdots$ & $\cdots$ & $\cdots$ & $\ldots$ & $4 / 6$ & $3 / 6$ & $6 / 6$ & $4 / 6$ & $2 / 6$ & $5 / 6$ & $\cdots$ & $\cdots$ \\
\hline \multirow[t]{2}{*}{ Petals } & Inoculation & $\ldots$ & $\ldots$ & $\ldots$ & $\ldots$ & $5 / 6$ & $\ldots$ & $\ldots$ & $\ldots$ & $\ldots$ & $\ldots$ & $\ldots$ & $\ldots$ \\
\hline & AmpliDet RNA & $\cdots$ & $\cdots$ & $\cdots$ & $\ldots$ & $5 / 6$ & .. & $\ldots$ & $\ldots$ & $\cdots$ & ... & $\cdots$ & $\cdots$ \\
\hline \multirow[t]{2}{*}{ Fruit } & Inoculation & $\ldots$ & $\ldots$ & $\ldots$ & $\ldots$ & $\ldots$ & $\ldots$ & $\ldots$ & $0 / 6$ & $0 / 6$ & $0 / 6$ & $0 / 6$ & $\ldots$ \\
\hline & AmpliDet RNA & $\ldots$ & $\ldots$ & $\ldots$ & $\ldots$ & $\ldots$ & $\ldots$ & $\ldots$ & $4 / 6$ & $4 / 6$ & $5 / 6$ & $6 / 6$ & $\ldots$ \\
\hline
\end{tabular}

${ }^{a}$ For each month and each tissue type, the number of trees positive for ASPV per the total number of ASPV-infected trees tested is shown.

Its sensitivity and ability to detect all biologically characterized isolates present in a field trial $(9,10)$ and a number of partially characterized isolates showed the potential of this method. A comparison between AmpliDet RNA and mechanical inoculation onto herbaceous test plants was performed on different tissue samples of apple trees throughout the year. AmpliDet RNA enabled the consistent detection of ASPV in bark, buds, petals, and fruits year round. Detection of ASPV by mechanical inoculation to $N$. occidentalis $37 \mathrm{~B}$, which requires at least 3 weeks for symptom development (8), was generally much less reliable irrespective of the tissue used.

AmpliDet RNA was able to detect ASPV in all the different tissue samples tested, thus, providing the possibility to reliably detect ASPV throughout the year. Moreover, the detection time needed is reduced dramatically to only 1 day when using AmpliDet RNA. The method is a good addition to woody indexing, the current certification protocol accepted and used by inspection services (1).

Recently, several RT-PCR-based methods were described for the detection of ASPV in woody plant tissues like buds, leaves, and flower blossoms. Two isolates were detected in leaves collected in the spring and from August until leaf-fall (6), and optimization of this RT-PCR enabled the detection of a wide range of symptom-inducing ASPV isolates in woody indicator leaf tissue (16). Another RT-PCR system confirmed the consistent detection of ASPV in leaves (15), in contrast to studies showing that leaves are poor sources for detection of ASPV compared with buds or flower blossoms (13).

Unlike the described RT-PCR systems, AmpliDet RNA enabled the detection of ASPV in bark, buds, petals, and fruits, regardless of the time of sampling. All previously mentioned RT-PCR-based methods for the detection of ASPV include a two-step RT-PCR prior to the gel-based detection of the specific amplification products. Using AmpliDet RNA, amplification and detection are performed simultaneously in a single tube. This gel-free system decreases labor and misdiagnosis dramatically (i.e., carry-over contamination). In addition to this, several studies have already demonstrated that NASBA is more sensitive than RT-PCR $(4,12)$, thus, increasing the probability of detecting ASPV in samples with very low virus titers.

Published sequence alignments of several ASPV CP-encoding sequences from different isolates showed a sequence identity ranging between 82 and $99 \%(15,16)$. Combining the newly obtained sequences of this study with the extant ones confirmed the heterogeneity among all ASPV CP-related sequences (Fig. 3). Because the heterogeneity appeared to be isolate-related, this might imply that primers and molecular beacons designed from a more conserved region than the $\mathrm{CP}$-encoding region would further improve the reliability of the system for a broad-spectrum detection of ASPV isolates.

In conclusion, this study demonstrates that AmpliDet RNA has the potential to provide a rapid, robust, and sensitive detection of ASPV in nuclear stock plants, in vitro propagative material, and woody tissue samples, without the need for time-consuming and highly toxic nucleic acid extraction methods. The technique might be very useful in diagnostic screening procedures because the testing time needed is dramatically reduced from the current minimum of 12 to 24 weeks on woody plants (greenhouse indexing) or up to 2 years on woody indicators in the fields to 1 day.

\section{ACKNOWLEDGMENTS}

This work was supported by RTD contract FAIR5-PL97-3889 of the European Commission.

\section{LITERATURE CITED}

1. Anonymous. 1998. International working group on fruit tree virusesISHS. Detection of virus and virus-like diseases of fruit trees-laboratory assays, bioassays and indicators. Acta Hortic. 472:769-783.

2. Cameron, H. R. 1989. Pear vein yellows. Pages 175-181 in: Virus and Viruslike Diseases of Pome Fruits and Simulating Noninfectious Disorders. P. R. Friedlund, ed. Wash. State Univ. Coll. Agric. Home Econ. Res. Cent. Bull.

3. Compton, J. 1991. Nucleic acid sequence-based amplification. Nature 350:91-92.

4. Goossens, V. J., Blok, M. J., Christiaans, M. H., Sillekens, P., Middeldorp, J. M., and Bruggeman, C. A. 2000. Early detection of cytomegalovirus in renal transplant recipients: Comparison of PCR, NASBA, pp65 antigenemia, and viral culture. Transplant. Proc. 32:155158.

5. Jelkmann, W. 1994. Nucleotide sequences of apple stem pitting virus and of the coat protein gene of a similar virus from pear associated with vein yellows disease and their relationship with potex- and carlaviruses. J. Gen. Virol. 75:1535-1542.

6. Jelkmann, W., and Keim-Konrad, R. 1997. Immuno-capture polymerase chain reaction and plate-trapped ELISA for the detection of Apple stem pitting virus. J. Phytopathol. 145:499-503.

7. Kievits, T., van Gemen, B., van Strijp, D., Schukkink, R., Dircks, M., Adriaanse, H., Malek, L., Sooknanan, R., and Lens, P. 1991. NASBA isothermal enzymatic in vitro nucleic acid amplification optimized for HIV-1 diagnosis. J. Virol. Methods 35:273-286.

8. Koganezawa, H., and Yanase, H. 1990. A new type of elongated virus isolated from apple trees containing the stem pitting agent. Plant Dis. 74:610-614.

9. Leone, G., Lindner, J. L., Jongedijk, G., and van der Meer, F. A. 1995. Back transmission of a virus associated with apple stem pitting and pear vein yellows from Nicotiana occidentalis to apple and pear. Acta Hortic. 386:72-77.

10. Leone, G., Lindner, J. L., van der Meer, F. A., and Schoen, C. D. 1998. Symptoms on apple and pear indicators after back-transmission from Nicotiana occidentalis confirm the identity of Apple stem pitting virus with Pear vein yellows virus. Acta Hortic. 472:61-65.

11. Leone, G., van Schijndel, H., van Gemen, B., Kramer, F. R., and Schoen, C. D. 1998. A molecular beacon probe combined with amplification by NASBA enables homogeneous, real-time detection of RNA. Nucleic Acids Res. 26:2150-2155.

12. Lunel, F., Cresta, P., Vitour, D., Paya, C., Dumont, B., Frangeul, L., Reboul, D., Brault, C., Piette, J. C., and Huraux, J. M. 1999. Comparative evaluation of hepatitis C virus RNA quantitation by branched DNA, NASBA, and monitor assays. Hepatology 29:528-535.

13. MacKenzie, D. J., McLean, M. A., Mukerji, S., and Green, M. 1997. Improved RNA extraction from woody plants for the detection of viral 
pathogens by reverse transcription-polymerase chain reaction. Plant Dis. 81:222-226.

14. Martelli, G. P., and Jelkmann, W. 1998. Foveavirus, a new plant virus genus. Arch. Virol. 143:1245-1249.

15. Nemchinov, L., Hadidi, A., and Faggioli, F. 1998. PCR-detection of apple stem pitting virus from pome fruit hosts and sequence variability among viral isolates. Acta Hortic. 472:67-73.

16. Schwarz, K., and Jelkmann, W. 1998. Detection and characterization of European apple stem pitting virus isolates of apple and pear by PCR and partial sequence analysis. Acta Hortic. 472:75-85.

17. Stouffer, R. F. 1989. Apple stem pitting. Pages 138-144 in: Virus and Viruslike Diseases of Pome Fruits and Simulating Noninfectious Dis- orders. P. R. Friedlund, ed. Wash. State Univ. Coll. Agric. Home Econ. Res. Cent. Bull.

18. Stryer, L. 1978. Fluorescence energy transfer as a spectroscopic ruler. Annu. Rev. Biochem. 47:818-846.

19. Tyagi, S., and Kramer, F. R. 1996. Molecular beacons: Probes that fluoresce upon hybridization. Nat. Biotechnol. 14:303-308.

20. Tyagi, S., Marras, S. A. E., and Kramer, F. R. 2000. Wavelength-shifting molecular beacons. Nat. Biotechnol. 18:1191-1196.

21. Yanase, H., Mink, G. I., Sawamura, K., and Yamaguchi, A. 1990. Apple topworking disease. Pages 74-75 in: Compendium of Apple and Pear Diseases. A. L. Jones and H. S. Aldwinckle, eds. The American Phytopathological Society, St. Paul, MN. 